\title{
Comparative description of males of two species of Achtheres von Nordmann, 1832 (Copepoda: Siphonostomatoida: Lernaeopodidae) infecting zander and European perch
}

\author{
Wojciech Piasecki, Agnieszka Sękowska-Jakubowska and Ewa Sobecka
}

Division of Fish Diseases, Agricultural University of Szczecin, ul. Kazimierza Królewicza 4, 71-550 Szczecin, Poland

Key words: parasitic copepod, male, morphology, systematics, Achtheres sandrae, Achtheres percarum

\begin{abstract}
Achtheres percarum von Nordmann, 1832 and Achtheres sandrae Gadd, 1901 (Lernaeopodidae) are common parasitic copepods infecting fishes in Eurasia. The former is specific to perch, Perca fluviatilis L., while the latter, to zander, Sander lucioperca (L.). Until recently these copepods have been regarded a single species. The present study was intended to analyse details of male morphology and provide their complete descriptions with differential diagnosis. Males of $A$. percarum and $A$. sandrae were collected from perch and zander at Lake Dąbie (north-western Poland). The males of $A$. sandrae are larger than those of $A$. percarum. They also differ in proportions of the first antenna, mandibular denticulation, structure of the first maxilla, and the armament of caudal ramus. The reported differences in male morphology constitute a conclusive confirmation of the separate identity of the two species.
\end{abstract}

Copepods of the genus Achtheres von Nordmann, 1832 (Lernaeopodidae), common fish parasites of Holarctic freshwater fishes, have been regularly studied by fish parasitologists in Europe (e.g. Kozikowska et al. 1956, Piasecki and Wołoszyn 1991, Valtonen et al. 1993). Intensive outbreaks in Tennessee and Virginia have recently focused attention of American ichthyopathologists and aquaculturists (Negus 2005, Wilson 2005) on these copepods. In European perch, Achtheres copepods tend to attach to the walls of the buccal cavity (palate, tongue, and gill arches) whereas in zander they are quite common on the gill lamellae. The attachment of a female to gill filament causes necrosis of the filament part distal to the point of attachment. Achtheres females attach permanently through a special structure called bulla, which is formed in the frontal organ (interantennary organ) (Piasecki 1993). The bulla becomes permanently connected to tips of second maxillae. The second maxillae of lernaeopodid females are usually elongate and they resemble longer or shorter "arms" holding the parasite at a single place throughout its entire life. The pathogenicity of those copepods can also be attributed to chalimus larvae of Achtheres attaching through their frontal filaments and inducing visible hypertrophy of the gill epithelium (Piasecki and Wołoszyn 1991). Achtheres males retain mobility and, in cases of high intensity of infection, can be frequently found on the gills of fish. They live shorter than the females, but are capable of feeding on the gills, also contributing to the pathogenicity (Piasecki, unpubl.).

The family Lernaeopodidae covers 65 nominal genera (of which 46 are valid) and over six hundred nominal species and subspecies. According to Kabata (1986) the number of valid species is approximately 250 . The family can be tentatively divided into two branches: marine and freshwater (Kabata 1979). The latter comprises seven genera: Tracheliastes von Nordmann, 1832; Pseudotracheliastes Markewitsch, 1956; Coregonicola Markewitsch, 1936; Basanistes von Nordmann, 1832; Cauloxenus Cope, 1872; Salmincola Wilson, 1915; and Achtheres von Nordmann, 1832. A total of 14 nominal species has been described in the genus Achtheres. Kabata $(1969,1979)$ postulated that only six of them were valid. In his more recent work Kabata (1988) rejected three further species. Recently, Kempter et al. (2006), based on detailed morphometric and molecular studies, postulated that the copepods hitherto identified as Achtheres percarum are in fact two separate species: Achtheres percarum von Nordmann, 1832 and Achtheres sandrae Gadd, 1901. The former is specific to perch, Perca fluviatilis L., while the latter, to zander, Sander lucioperca (L.). The morphological differences between the females of these two species are in their body proportions, size of genital process, armaments of the second antenna and the maxilliped.

Kabata (1979), based on patterns in the body structure of lernaeopodid males, assigned them to three types: A, B, and C.

The most common type is " $\mathrm{A}$ ", comprising not only all freshwater genera, but also many marine ones. The body of type-A male, exemplified by freshwater genera, consists of two parts: the cephalothorax and the genitoabdominal complex. Those two parts are comparable in size and are in line with each other. The genitoabdominal complex (also referred to as the trunk) is equipped with two pairs of vestigial legs (Piasecki 1989) and caudal rami. A variety of the type-A males, represented by Lernaeopoda de Blainville, 1822 (known as elasmo- 
branch parasites), has a distinctly inflated cephalothorax, inclined ventrally at a slight angle. The vestigial legs are present and caudal rami are enlarged and deflected dorsally and forward. According to Kabata (1979), also males of Charopinus Krøyer, 1863 belong to type A. Their caudal rami point posteriorly and the flexion angle between the major body parts is sharper than in Lernaeopoda. Males of the Brachiella group (Brachiella Cuvier, 1830) are similar to those of Charopinus group, but they have rather small caudal rami.

A good example of the lernaeopodid type-B male is the genus Clavella Oken, 1816. Its principal feature is almost complete reduction of the trunk. Related genera may have the trunk transformed into a posteriorly rounded sac. The body is dramatically shortened, giving the male a semispherical appearance, with cephalothoracic appendages crowding on the ventral side.

The type $\mathrm{C}$ of lernaeopodid males can be exemplified by Euclavellisa Heegaard, 1940 and Nectobrachia Fraser, 1920, representing an intermediate condition between types A and B.

Males of $A$. percarum were first described and illustrated by von Nordmann (1832) and redescribed by Gurney (1933). Both descriptions were only general, providing few details. No complete description of males of A. sandrae has been published as yet. Piasecki (1993) described selected fine structures of this parasite (although under the name of $A$. percarum).

\section{MATERIALS AND METHODS}

Males of $A$. percarum and $A$. sandrae were collected, respectively, from perch and zander captured by commercial fishermen at Lake Dąbie and Szczecin Lagoon, north-western Poland in 1999, 2004, and 2005. A total of 4 specimens of $A$. sandrae and 8 of $A$. percarum was collected. They were cleared in lactic acid and observed under a compound microscope (Olympus BX 50) following a modified "wooden slide method" (Humes and Gooding 1964). Appendages of the males were dissected using fine needles. All appendages were illustrated with the aid of a drawing tube. Terminology used follows that of Kabata (1979) (with one exception).

All available specimens of Achtheres males were drawn, using a drawing tube, and subsequently measured, along the long axis from the frontal area to the caudal end (excluding caudal rami).

\section{RESULTS}

Males of both species represent type A (Kabata 1979) and are similar in general view, differing in details of their appendages and other structures. Therefore their description, although based on separate illustrations, is presented jointly and the differences are emphasised where applicable.

Body elongate and distinctly divided into two parts: cephalothorax and posterior genital trunk (Figs. 1, 2). Former unsegmented, armed with small appendages surrounding mouth cone: first antenna (A1), second antenna (A2), mandible (Mdb), and first maxilla (Mx1) and prominent prehensile appendages: second maxilla (Mx2) and maxilliped (Mxp) in ventral area. Large thick-walled medial process located between maxillipeds (Fig. 2). Genital trunk elongate, fusiform, and slightly larger than cephalothorax, showing weak traces of segmentation and featuring two pairs of vestigial legs (P1 and P2) and caudal rami (Figs. 1, 2). Body cuticle thick and elastic, except for Mx2 and Mxp, where rigid and sclerotised.

Overall length of $A$. percarum (Fig. 1) was $1.61 \pm$ $0.11 \mathrm{~mm}(1.63-1.69 ; \mathrm{n}=8)$, while that of $A$. sandrae (Fig. 2) amounted to $2.07 \pm 0.46 \mathrm{~mm}(1.64-2.63 ; \mathrm{n}=4)$.

Upper lip (labrum) forming, together with labium, mouth cone. Cuticular flaps near central part of labrum similar in both species (illustrated for $A$. sandrae by scanning electron micrographs by Piasecki 1993).

First antenna (A1) (Figs. 3, 4) 3-segmented with well-developed apical armature (with 6 elements, including 2 long setae). In $A$. percarum A1 (Fig. 3) accounting for $8.6 \%$ of total length of male, while in $A$. sandrae (Fig. 4) A1 more elongate, constituting 13.7\% of total male length. Basal segment twice as long as other two, armed with reduced whip, located medially. Reduced solus (not illustrated) ventrally on second segment near junction with terminal segment. Lengthwidth ratio of terminal segment approximating 2 in $A$. percarum and 3 in $A$. sandrae. Length of intersegmental joint area between terminal- and second segment in $A$. percarum less than $10 \%$ of A1 width at this point while in A. sandrae $150 \%$ of A1 width. Cuticle of intersegmental joint thick enough to support rigidity of appendage.

Second antenna (A2) (Figs. 5, 6) prehensile, biramous; exopod one-segmented, bulbous, armed with two prominent denticles. Two-segmented endopod of similar length in both species, with typical lernaeopodid armament (hook 1, seta 2, tubercle 3, spinulate pad 4, and process 5) (cf. Kabata 1969). Endopod almost twice as long as exopod.

Mandible (Mdb) (Figs. 7, 8). Distal edge of terminal blade armed with 9 teeth curved towards base. Basal teeth slightly diminishing in size towards base. In $A$. percarum third tooth secondary; mandibular formula: P1, P1, S1, B6 (Fig. 7) In A. sandrae third tooth secondary and fourth tooth primary. Latter much smaller than second tooth. Mandibular formula P1, P1, S1, P1, B5 (Fig. 8).

First maxilla (Mx1) (Figs. 9, 10) biramous, with prominent endopod fused with sympod and small reduced exopod in form of short papilla ending with minute seta or process. Endopod with three large papillae, third from tip smaller than other two, each papilla terminating in strong seta. In A. percarum (Fig. 9) third papilla $(+$ seta $)$ only slightly smaller than other two, while in $A$. sandrae (Fig. 10) constituting only half size of other two. Exopod in A. sandrae smaller than that in A. percarum. 


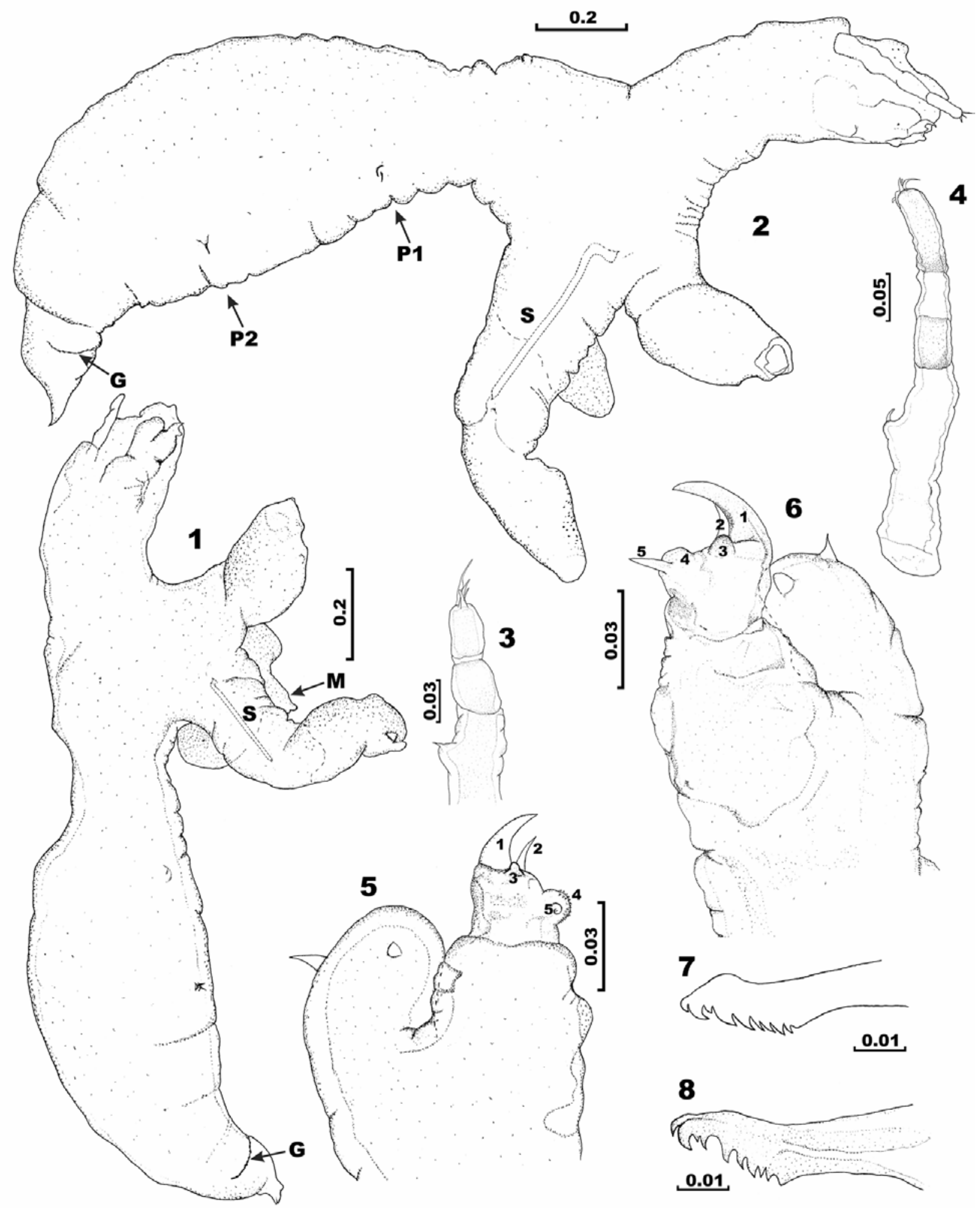

Figs. 1-8. Achtheres percarum and Achtheres sandrae, male. Fig. 1. A. percarum, lateral view. Fig. 2. A. sandrae, lateral view. Fig. 3. A. percarum, first antenna, anterior view. Fig. 4. A. sandrae, first antenna, anterior view. Fig. 5. A. percarum, second antenna. Fig. 6. A. sandrae, second antenna. Fig. 7. A. percarum, mandible. Fig. 8. A. sandrae, mandible. Abbreviations: $\mathrm{G}-$ genital fold; M - medial process; P1 - first leg; P2 - second leg; S - internal sclerite; parts of A2 numbered according to Kabata (1969). Scale bars in mm. 

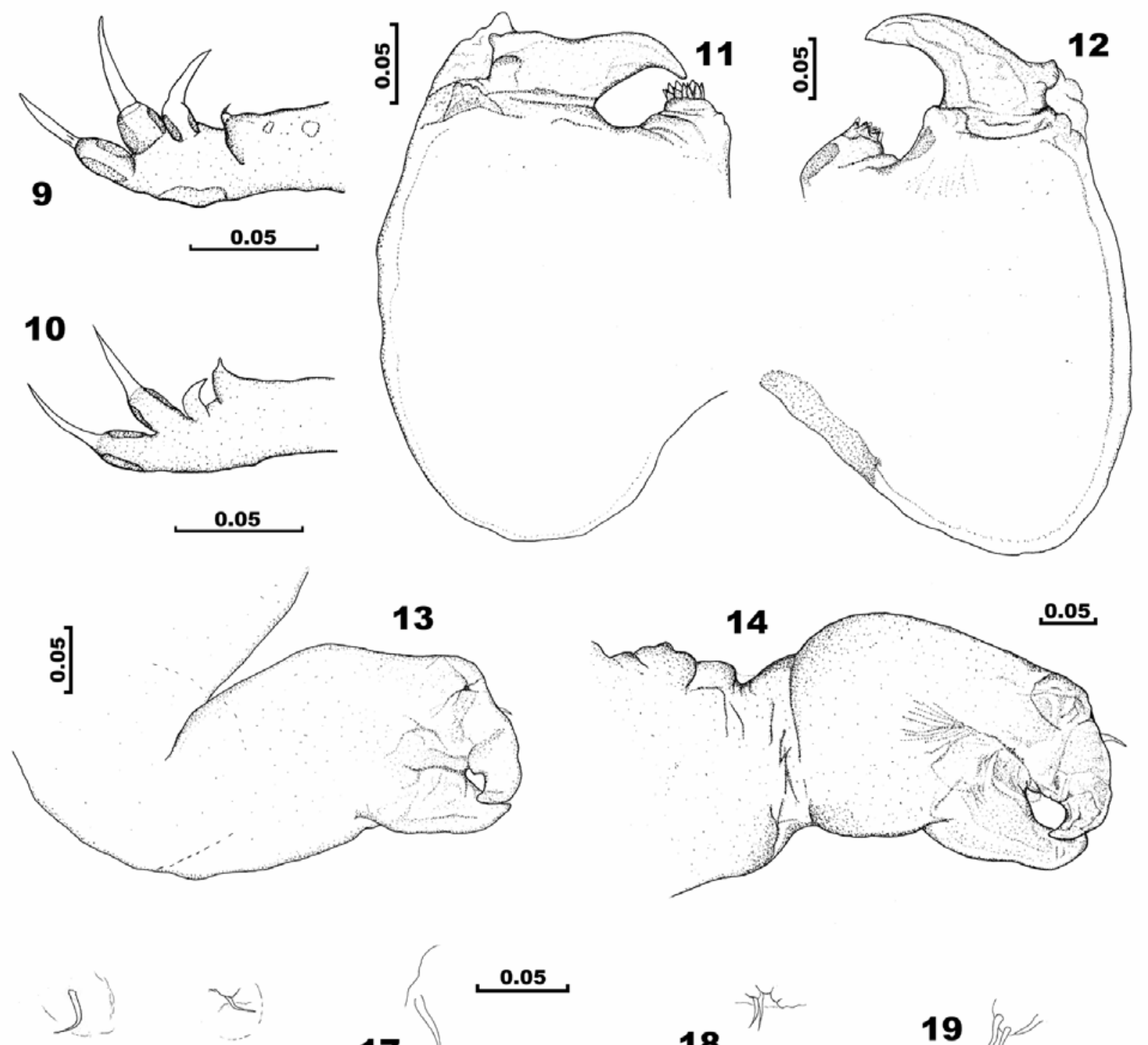

15

\section{6}

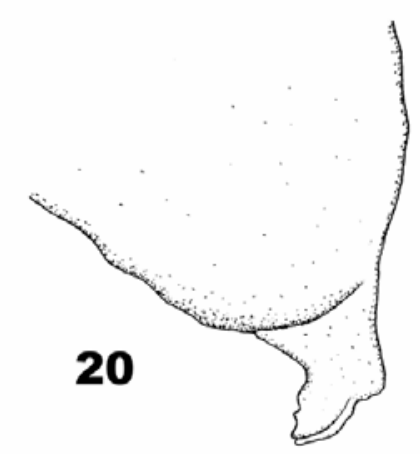

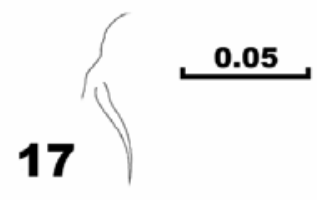

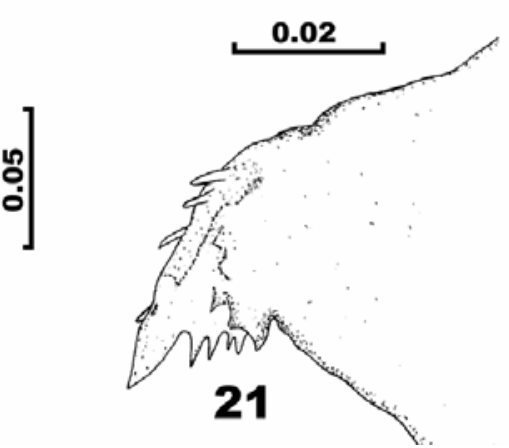

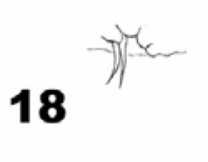

19

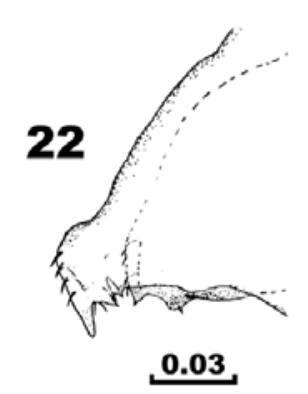

Figs. 9-22. Achtheres percarum and Achtheres sandrae, male. Fig. 9. A. percarum, first maxilla. Fig. 10. A. sandrae, first maxilla. Fig. 11. A. percarum, second maxilla. Fig. 12. A. sandrae, second maxilla. Fig. 13. A. percarum, maxilliped. Fig. 14. $A$. sandrae, maxilliped. Figs. 15, 16. A. percarum, first leg. Fig. 17. A. sandrae, first leg. Fig. 18. A. percarum, second leg. Fig. 19. A. sandrae, second leg. Fig. 20. A. percarum, caudal ramus, lateral view. Figs. 21, 22. A. sandrae, caudal ramus, lateral view. Scale bars in $\mathrm{mm}$. 
Second maxilla (Mx2) (Figs. 11, 12) subchelate, prominent, short and squat, with thick cuticular wall, with length:width ratio approximating 1 in anterior view, and 2 in lateral view. Subchela with broad base, shaft fused with pointed claw. Medial side of corpus equipped with distinct outgrowth (myxa) covered with 10-11 big denticles. Tip of subchela opposing denticulate myxal pad.

Maxilliped (Mxp) (Figs. 13, 14) subchelate (almost chelate), consisting of three segments: sympod, corpus, and subchela. Sympod and corpus longer than wide (Figs. 1, 2); subchela shorter than corpus width (Figs. $13,14)$. Subchela shaft with single seta near base, fused with blunt claw. Subchela closing against large, elongate process, with tip almost exceeding corpus length. Sympod containing powerful stick-like sclerite inside (Figs. 1, 2).

First leg (P1) (Figs. 15-17) vestigial, consisting of single small seta.

Second leg (P2) (Figs. 18, 19) vestigial, consisting of two small setae.

Caudal ramus (Figs. 20-22) short, digitiform process. In A. percarum (Fig. 20) equipped with relatively blunt process pointed ventrally. In A. sandrae (Figs. 21, 22 ), terminal process distinctly more elongate, showing extensive variability, usually covered by additional sharp denticles; rarely unarmed.

External genitalia in form of inconspicuous cuticle folds in posterior part of trunk (Figs. 1,2).

\section{DISCUSSION}

The number of valid species of Achtheres has been reduced within recent four decades. There were 14 nominal species. Some were transferred to Salmincola Wilson, 1915 (cf. Kabata 1969) while others relegated to synonymy, leaving only 6 treated as valid by Kabata (1979). According to Kabata (1988) there are only three valid species of this genus (A. percarum von Nordmann,
1832, A. pimelodi Krøyer, 1863, and (?) A. lacae Krøyer, 1863).

The trend in reduction of the number of valid species has been balanced by research generating evidence for the separate specific identity of copepods infecting different host species. Kozikowska et al. (1956) for example, tried to determine the true identity of copepods from perch and zander. Recently, Kempter et al. (2006), using morphometry and molecular methods, proved that Achtheres from perch and zander are indeed two separate species and consequently $A$. sandrae Gadd, 1901 should be re-established as a valid species.

The present work, showing morphological differences between male Achtheres copepods from perch and those from zander, provides further evidence for the recognition of the two European species of this genus. The two males clearly differ in a number of characters, the first antenna being the most evident. The infection parameters of Achtheres spp. fluctuate between years (Piasecki and Wołoszyn 1991, Valtonen et al. 1993, Piasecki unpubl.) and this, combined with generally very low abundance of lernaeopodid males (Piasecki 1986), contributes to the difficulty in providing measurements of representative sample of males. Molecular evidence presented by Kempter et al. (2006) of a narrow host specificity of $A$. percarum and $A$. sandrae, supported by the presently reported findings, suggests that the taxonomic identity of their American congeners should also be reconsidered in the future.

The typology of lernaeopodid males proposed by Kabata (1979) needs elaboration and a revision. It is very likely that types A and B will split into many separate types.

The presently reported internal sclerite inside the maxilliped sympod is quite unique in the respect of its structure and function. Because of its internal position it mimics an element of internal skeleton know from vertebrate limbs (e.g., femur). Its function is unknown but we can speculate that it is needed for reinforcement of the limb during copulation.

\section{REFERENCES}

GURNEY R. 1933: British Fresh-Water Copepoda. Vol. 3. The Ray Society, London, $384 \mathrm{pp}$.

HUMES A.G., GOODING R.U. 1964: A method for studying the external anatomy of Copepoda. Crustaceana 6: 238240.

KABATA Z. 1969: Revision of the genus Salmincola Wilson, 1915 (Copepoda: Lernaeopodidae). J. Fish. Res. Board Can. 26: 2987-3041.

KABATA Z. 1979: Parasitic Copepoda of British Fishes. The Ray Society, London, 468 pp.

KABATA Z. 1986: Redescriptions of and comments on four little-known Lernaeopodidae (Crustacea: Copepoda). Can. J. Zool. 64: 1852-1859.

KABATA Z. 1988: Copepoda and Branchiura. In: L. Margolis and Z. Kabata (Eds.), Guide to the Parasites of Fishes of
Canada. Part II - Crustacea. Canadian Special Publication of Fisheries and Aquatic Sciences 101, pp. 3-127.

KEMPTER J., PIASECKI W., WIĘSKI K., KRAWCZYK B. 2006: Systematic position of copepods of the genus Achtheres (Crustacea: Copepoda: Siphonostomatoida) parasitizing perch, Perca fluviatilis L., and zander, Sander lucioperca (L.). J. Fish Dis. 29: 103-113.

KOZIKOWSKA Z., JARA Z., GRABDA E. 1956: Achtheres percarum Nordm. Sur la perche et la sandre (Essai D'Explication de la relation mutuelle des formes: percarum et sandrae). Zool. Pol. 7: 219-267. (In Polish with French and Russian summaries.)

NEGUS J. 2005: "Gill maggot" infestation in Tennessee. http://www.tnfish.org/Achtheres/Achtheres.htm 
von NORDMANN A. 1832: Mikrographische Beiträge zur Naturgeschichte der wirbellosen Thiere. Vol. 2. Reimer, Berlin, $150 \mathrm{pp}$.

PIASECKI W. 1986: Description of the male of Tracheliastes maculatus Kollar, 1835 (Siphonostomatoida, Lernaeopodidae). Syllogeus 58: 584-588.

PIASECKI W. 1989: Life cycle of Tracheliastes maculatus Kollar, 1835 (Copepoda, Siphonostomatoida, Lernaeopodidae). Wiad. Parazytol. 35: 187-245.

PIASECKI W. 1993: Interantennary organ of Achtheres percarum von Nordmann, 1832 (Copepoda, Siphonostomatoida, Lernaeopodidae) and some other new details of its external morphology. Acta Parasitol. 38: 36-40.

PIASECKI W., WOŁOSZYN A. 1991: [Mass infection of Achtheres percarum von Nordmann, 1832 (Copepoda, Si-

Received 3 October 2005 phonostomatoida, Lernaeopodidae) in perch Perca fluviatilis L. in the estuary waters of the Odra River.] Materiały XVI Zjazdu Polskiego Towarzystwa Parazytologicznego, Poznań, 12-13 Sept. 1991, p. 27. (In Polish.)

VALTONEN E.T., TUUHA H., PUGACHEV O.N. 1993: Seasonal studies of the biology of Achtheres percarum in perch, Perca fluviatilis, from four Finnish lakes over a 3year period. J. Fish Biol. 43: 621-632.

WILSON D.M. 2005: Striped bass parasites, are they killing striped bass or just biologists? Southern Division of the American Fisheries Society 2005 Spring Meeting, Virginia, Meeting Abstracts, p. 54. http://www.sdafs.org/ meetings/05sdafs/2005_web_abstracts.pdf

Accepted 9 May 2006 